\title{
PALEOECOLOGY OF AN ARCTIC ESTUARY
}

\author{
Richard W. Faas*
}

\begin{abstract}
An alternating sequence of black silt and clay units, and coarse sand and gravel units, has been found to depths of $30 \mathrm{ft}$. below sea level in the sediments underlying an arctic estuary. The black silt and clay units, containing pitted foraminiferal tests, were deposited in an anaerobic environment while the estuary was isolated from the ocean by a gravel bar across its mouth. The sand and gravel units, containing pelecypod fragments, resulted from the destruction and spreading of the gravel bar inland under marine conditions. A radiocarbon date at the base of the sequence indicates these conditions first occurred 6,450 years ago.
\end{abstract}

RESUMÉ. Paléócologie d'un estuaire arctique. On a trouvé, dans les sédiments tapissant un estuaire arctique, une séquence alternée d'horizons de limon noir et d'argile et d'horizons de sable grossier et de gravier, s'étageant jusqu'à une profondeur de 30 pieds $(9.14 \mathrm{~m}$.) sous le niveau de la mer. Le limon et l'argile contiennent des tests de foraminifères et se sont déposés en milieu anaérobie, au moment où une flèche de gravier accumulée en travers de l'embouchure isolait l'estuaire de l'océan. Le sable et le gravier contiennent des fragments de pélécypodes et résultent de la destruction et de l'étalement de cette flèche en milieu marin. Une datation au radiocarbone, au bas de la séquence, indique que ces conditions sont apparues il y a 6,450 ans.

АБ̄СТРАКТ, ПАЛЕОЭКОЛОГИЯ АРКТИЧЕСКОГО ЭСТУАРИЯ. ЧередУющаяСЯ Последовательность черных осадков с глиной и песка с гравием была обуаружена до 30 футов ниже уровня моря в отложениях подствлающи арктический эстуарий. Черные осадки с глиной, содержащие образцы ямчатых фораминифер, были образованы в анаэробной обстановке, когда әстуарпй был пзолирован от океана поперечной грлдой травия в устье. Песок и гравий, содержащие фрагменты пелециподов, явились в результате разрушения и расплыва гравийной гряды при морских условиях. Датировка радиоуглеродом на базе последовательности показывает, тто әти условия возникли 6.450 лет тому назад.

\section{Introduction}

T The Gubik Formation (Pleistocene) of northern Alaska consists of a surficial covering of unconsolidated silt, sand, and gravel deposits extending over an area greater than 26,000 square miles. A recent review (Black 1964) indicates that it is the product of many different depositional environments, dominated by near-shore shallow water marine conditions, and complicated by sediment changes associated with a shifting strandline. These conditions occurred at frequent intervals during the period represented by the sediments. This paper presents the results of the study of one of these strandline environments near Barrow, Alaska (Fig. 1), and may provide a reference point for understanding the regional variation observed in the sediments.

\section{Present Conditions}

The study area, Nerravak (Esatkuat) Lagoon, is a 5,100 by 2,000 ft. nonventilated estuary lying directly northeast of the village of Barrow on the northern coast of Alaska (Fig. 1). The estuary is composed of three separate basins: a central body occupying an oblong trough, gradually deepening to a maximum of $11 \mathrm{ft}$. in the centre; a smaller western basin which drops quite steeply to a depth of $8 \mathrm{ft}$; an eastern basin, possessing a sinuous channel with a nearly

\footnotetext{
"Department of Geology, Lafayette College, Easton, Pennsylvania, U.S.A.
} 


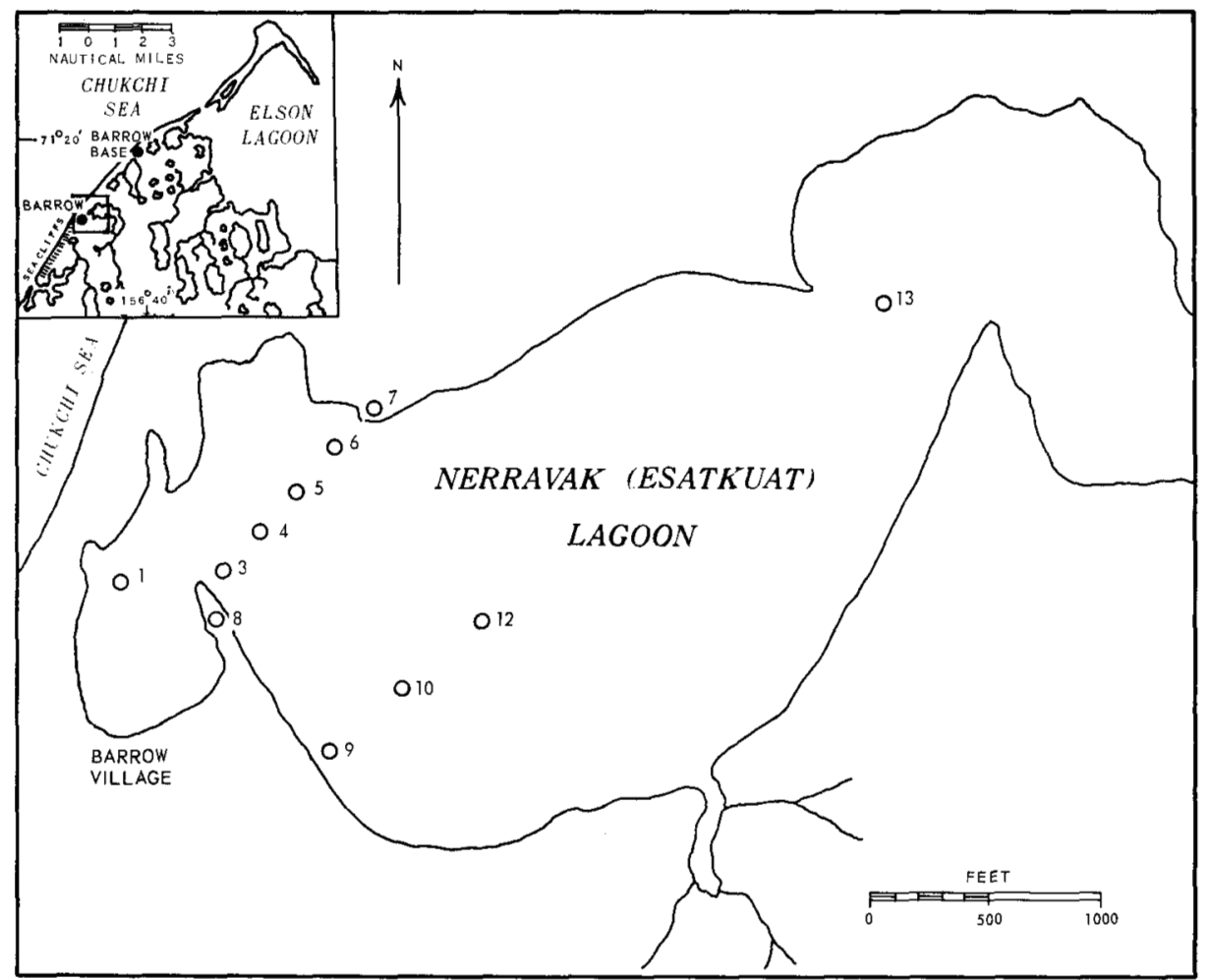

Fig. 1. Map of Nerravak (Esatkuat) Lagoon near Barrow, Alaska, showing the location of all the drill holes from which sediments were taken. Study area is indicated by rectangle in inset map.

constant depth of $11 \mathrm{ft}$, extending some distance back into the tundra. The last-mentioned basin is separated from the central basin by a submerged gravel sill over which the water is about $2 \mathrm{ft}$. deep.

The salinity of the estuary varies considerably. Water analyses performed in 1957 by the Bureau of Indian Affairs (R. D. Buchanen, personal communication, 1965 ) indicates a salinity range of 0.84 to $46.98 \%$, from the spring immediately after the breakup of the ice to the winter under total ice cover. The high winter salinity is due to normal desalting processes accompanying ice formation during which brines become concentrated and migrate downward through the ice, enriching the unfrozen bottom waters. The low spring salinity is caused by the vast amount of fresh melt water that flows from the surrounding tundra during the thaw.

A gravel bar extends across the mouth of the estuary and prevents normal interchange of estuarine and oceanic waters for a large part of each year. The bar is breached during the spring runoff and usually remains open until repaired by longshore currents which do not become effective until the ocean ice has moved out to sea. This may be as late as the end of July, but is usually sooner. Inasmuch as the tidal range is no greater than 6 in., ingress of oceanic waters during this open period is not great. In fact, the outflow of fresh water through the break is probably the dominant factor during this time. Some percolation 
through the coarse gravel bar may occur after it is sealed but, in view of the low tidal range, such circulation is probably not effective in substantially changing the ionic composition of the waters.

Brewer (1958) indicates that lakes in the Barrow area exhibit a yearly temperature range of $0^{\circ}$ to $12^{\circ} \mathrm{C}$. with near isothermal conditions prevailing throughout the water column at any given time. Under these temperatures, the amount of dissolved oxygen in the water can range from 6.5 to $8.0 \%$. If so, it is most probably consumed by decompositional processes during the long period of ice covering, leading to oxygen depletion of the entire basin.

The bottom sediments of Nerravak (Esatkuat) Lagoon are dominated by the foraminifer Elphidium, a well-known inhabitant of marginal environments. The tests of these organisms are calcareous and many exhibit missing chambers and surficial pitting. Burial in acidic muds, corresponding to anaerobic conditions, would cause such solution features.

\section{Sediments}

It is unlikely that the normal condition of the estuary is aerobic. The sediment on the modem estuary bottom is characteristically a black, sticky, foulsmelling mud, indicating deposition under reducing conditions. Holmquist (1963) found similar sediments in Sinclair Lake (locally Lake Minga) located about 46 miles to the southeast of Barrow and attributed their occurrence to a deficiency of oxygen. Other lakes sampled in the Barrow area (Holmquist 1963; Mohr et al 1961) showed no evidence of an oxygen deficiency at the time of sampling; however, black bottom muds were found, indicating that perhaps anaerobic conditions occurred intermittently, probably during the winter ice-covered period.

Two distinct lithologic units can be recognized: (1) a lower unit extending from $30 \mathrm{ft}$. below sea level to about $70 \mathrm{ft}$. below sea level; and (2) an upper unit extending from $30 \mathrm{ft}$. below sea level up to the present estuary bottom. The lower unit is dominantly coarse silt and fine- to medium-grained sand. Organic matter, determined by wet oxidation (Maciolek 1962) averages 3 per cent. The sediments are non-fossiliferous except for sporadic occurrences of a few foraminifera which appear to have been reworked. Cores show that the sediments are generally uniform in texture, interrupted by occasional thin lenses of organic-rich silt and clay. This unit appears to be lithologically similar to the Barrow unit (Black 1964) and a correlation is suggested.

The sediments of the upper unit contain two, and possibly three units of black, fetid, highly organic silt and clay, separated by a coarser brownish-yellow to greenish-gray gravelly sand containing lenses and pockets of gray to black silt and clay (Fig. 2). The black units are fossiliferous, containing ostracodes, foraminifera and chitinous insect parts. The coarser units are also fossiliferous (pelecypod fragments, foraminifera, and ostracodes), have low organic matter (average 3.4 per cent) and in places exhibit a particle size gradient, with coarser gravels inland and finer particles seaward.

\section{Laminations}

Regularly alternating laminations of black (3/4-inch thick) and brown (1/2inch thick) silt have been observed in several cores from the fine-grained units. Organic contents are high in both, averaging 13 per cent in the black silt and 


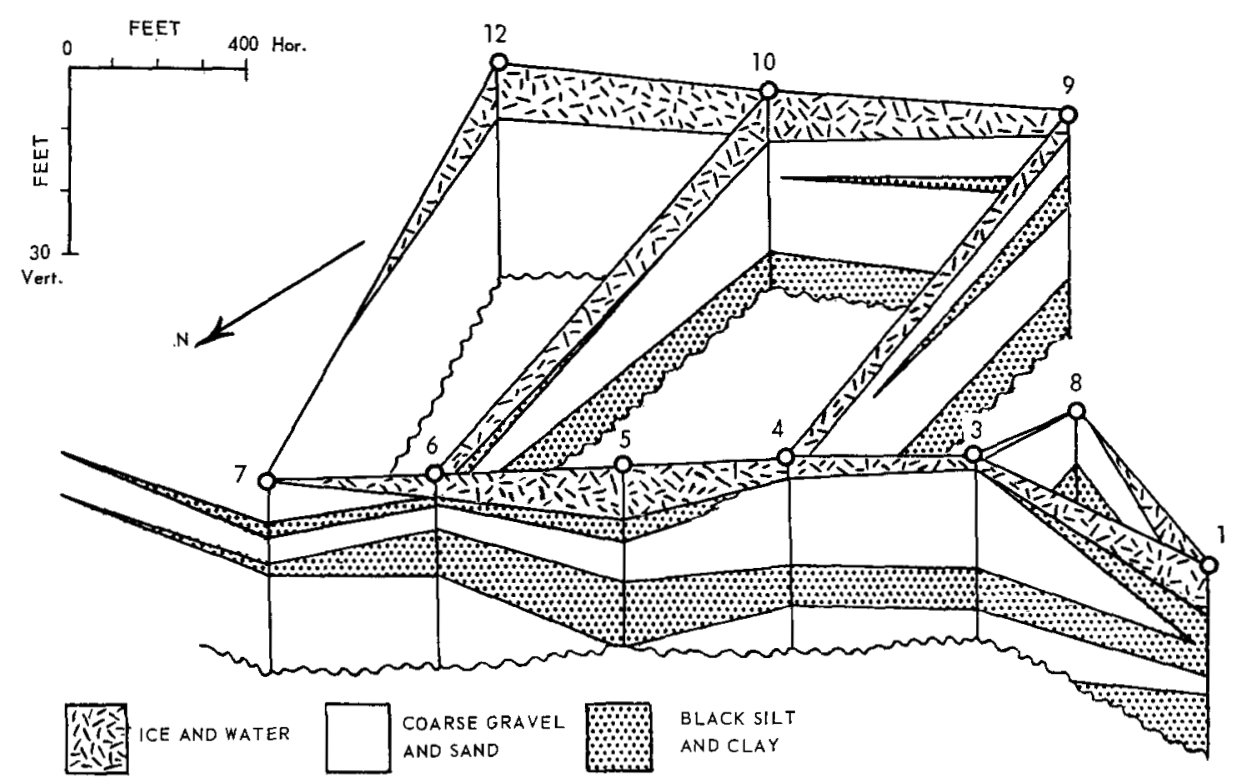

Fig. 2. Panel diagram showing spatial and stratigraphic position of coarse and fine-grained units. (See Fig. 1).

8.5 per cent in the brown silt. It is believed that these laminations may be used to establish a minimum depth for Nerravak (Esatkuat) Lagoon during the periods of non-ventilation. It is known that, during an average winter, the ice on many shallow lakes (less than $6 \mathrm{ft}$. deep) freezes completely to the bottom. During March 1962, $6 \mathrm{ft}$. of ice was measured on Nerravak (Esatkuat) Lagoon. In the spring thawing begins at the shore margins, and in time a zone of free water exists at the perimeter of the basin, between the shoreline and the central ice body. The less dense ice mass then rises, carrying with it several inches of bottom sediment which is redistributed throughout the basin as the ice melts. This process interferes with the normal settling of fine particles and organic matter and destroys any laminations that may have formed during the preceding summer. Consequently, laminations must have developed free from the influence of this process, requiring the estuary to be at least $6 \mathrm{ft}$. deep and probably deeper.

The laminations also support the conclusions concerning the anaerobic conditions in the estuary. Unfavourable environmental conditions will restrict the populations of burrowing organisms which normally rework the sediment. Under these conditions, deposition would proceed undisturbed and distinct laminations would form.

\section{History}

A sample of wood ( $\mathrm{T} x-220)$ from the base of the initial black clay unit in Hole \#4 (34 to $361 / 2 \mathrm{ft}$. below sea level) has been radiocarbon dated at 6,450 \pm 200 years B.P. (Pearson et al 1965). It is believed that this wood was buried at or near sea level as the date corresponds well with the curve of eustatic change drawn by MacFarland (1961), Curray (1961, 1964), Bloom and Stuiver (1963), and Shephard (1964). This date must be considered the maximum as the wood 
could have been reworked from older sediments and redeposited. The estuarine sequence is thought to reflect either brief periods of tectonic instability, storms of considerable intensity, or slight rises in sea level within the past 6,450 years. The black clay units at $30 \mathrm{ft}$. and $17 \mathrm{ft}$. below sea level record times when the estuary was sealed off from the ocean by a gravel bar and anaerobic conditions developed. The coarse, fossiliferous unit between the black clay units indicates destruction of the bar and the spread of the bar material over the pre-existing black clays. Fossils in the coarse unit indicate marine conditions but they could as easily have been supplied from the eroding cliffs south of Barrow village. Development of the bar, either by longshore currents or ice-shove, may have proceeded under conditions of rising sea level when erosion of the cliffs must have occurred at increased intensity.

The magnitude of sea-level rise need not have been great. Fluctuations of several feet may have been sufficient to top the bar and cause the spreading of the coarse material. On the other hand, high onshore winds combined with open water conditions could create sufficient waves to destroy the bar, particularly if operating consistently from seaward and over several days. These conditions occurred during the storm of 3 October 1963, after which it was estimated that approximately 200,000 cubic yards of sand and gravel were added to Point Barrow, over 20 years of normal net transport (Hume 1965). During this storm, wind gusts up to 75 miles per hour developed a storm surge of 11 to $12 \mathrm{ft}$. which was sufficient to flood much of the low lying area within $1 / 2$ to $3 / 4$ mile from the present shoreline. This includes Nerravak (Esatkuat) Lagoon.

Slight tectonic disturbances would also account for the interruption of anaerobic conditions. Lachenbruch (1957), however, presents thermal profiles that indicate no active tectonism for the last several thousand years. Whether such stability has been maintained for a longer period has not been established.

At this stage it is difficult to determine the actual mechanism whereby the coarse gravels were spread over the black clays, followed by the development of another black clay unit. Periodic storms alone could account for the observed facts, but it seems desirable also to consider the possibility that they may have been produced as the result of slight sea-level fluctuations imposed upon the general eustatic rising trend which occurred following the culmination of the Wisconsin ice sheet. Evidence for short-term sea-level fluctuations within the past 2,000 years has been presented by Fairbridge (1961) and Hume (1965). Brown (1965) is continuing his radiocarbon dating and stratigraphic program which holds promise for some detailed information on these and earlier fluctuations in the near future.

\section{Acknowledgements}

The work on which this paper is based was performed under Subcontract ONR-316 with the Office of Naval Research, and was administered by the Arctic Institute of North America. The laboratory analyses were made in the Geology Department at Iowa State University. A grant from Lafayette College permitted further study of the estuarine sediments and microfossils.

Thanks are expressed to Mr. Max C. Brewer, Director of the Arctic Research Laboratory, for laboratory facilities and logistics during the field work; Dr. Jerry Brown and Paul V. Sellman (CRREL), and Dr. James Hume, Tufts University, for their comments and suggestions. 


\section{References}

Black, Robert F. 1964. Gubik formation of Quaternary age in northern Alaska. U.S. Geol. Surv. Prof. Paper 302-C, pp. 59-91.

Bloom, A. L. and Minze Stuiver. 1963. Submergence of the Connecticut coast. Science 139:332-34.

Brewer, M. C. 1958. The thermal regime of an arctic lake. Trans. Am. Geophys. Union 39: 278-84.

Brown, Jerry. 1965. Radiocarbon dating, Barrow, Alaska. Arctic 18: 36-48.

Curray, J. R. 1961. Late Quaternary sea level: a discussion. Bull. Geol. Soc. Amer. 72: 1707-12. 1964. Transgressions and regressions. In: Papers in Marine Geology, Shepard Commemorative Volume. R. L. Miller, ed.

Fairbridge, R. W. 1961. Eustatic changes in sea level. Physics and Chemistry of the Earth, Vol. IV. London: Pergamon Press, pp. 99-185.

Holmquist, C. 1963. Some notes on Mysis relicta and its relatives in northern Alaska. Arctic 16: $109-128$

Hume, J. D. 1965. Sea level changes during the last 2,000 years at Point Barrow, Alaska. Science 150: 1165-66.

1965. Shoreline changes near Barrow, Alaska caused by the storm of October 3, 1963, Final Report, submitted to Arctic Institute of North America under Subcontract ONR-343.

Lachenbruch, A. H. 1957. Thermal effects of the ocean permafrost. Geol. Soc. America Bull. 68: 1515-30.

MacFarland, E., Jr. 1961. Radiocarbon dating of late Quaternary deposits, south-Louisiana. Geol. Soc. America Bull. 72: 129-57.

Maciolek, J. A. 1962. Limnological organic analyses by quantitative dichromate oxidation. U.S. Dept. Int., Fish and Wildlife Service, Bureau of Sport Fisheries and Wildlife Res. Rept. 60.

Mohr, J. L., D. J. Reish, J. L. Barnard, R. W. Lewis, and S. R. Geiger. 1961. The marine nature of Nuwuk Lake and small ponds of the peninsula at Point Barrow, Alaska. Arctic 14: $211-23$.

Pearson, F. J., Jr., E. Mott Davis, M. A. Tamers, and Robert W. Johnstone. 1965. University of Texas radiocarbon dates III. Radiocarbon 7: 296-314.

Shepard, F. P. 1964. Sea level changes in the past 6,000 years: Possible archaeological significance. Science 143: 574-576. 